\title{
Luba Rhodes, "Un romantisme mitigé”. La vie et l'œuvre du sculpteur Chaponnière (1801-1835)
}

\section{Lise Sabourin}

\section{(2) OpenEdition}

1 Journals

\section{Édition électronique}

URL : http://journals.openedition.org/studifrancesi/9283

DOI : 10.4000/studifrancesi.9283

ISSN : 2427-5856

Éditeur

Rosenberg \& Sellier

\section{Édition imprimée}

Date de publication : 1 juin 2008

Pagination : 208

ISSN : 0039-2944

\section{Référence électronique}

Lise Sabourin, "Luba Rhodes, "Un romantisme mitigé". La vie et l'œuvre du sculpteur Chaponnière

(1801-1835) », Studi Francesi [En ligne], 154 (LII | I) | 2008, mis en ligne le 30 novembre 2015, consulté le 10 janvier 2021. URL : http://journals.openedition.org/studifrancesi/9283 ; DOI : https://doi.org/ 10.4000/studifrancesi.9283

Ce document a été généré automatiquement le 10 janvier 2021.

\section{(c)}

Studi Francesi è distribuita con Licenza Creative Commons Attribuzione - Non commerciale - Non opere derivate 4.0 Internazionale. 


\title{
Luba Rhodes, "Un romantisme
} mitigé". La vie et l'œuvre du sculpteur
Chaponnière (1801-1835)

\author{
Lise Sabourin
}

\section{RÉFÉRENCE}

LUBA RHODES, “Un romantisme mitigé”. La vie et l'œuvre du sculpteur Chaponnière (1801-1835), Genève, Slatkine, 2006, pp. 535, ill.

1 John-Étienne Chaponnière doit la célébrité de sa brève vie à sa Jeune Grecque pleurant sur le tombeau de Byron (1827) dont le succès au Salon de 1833 lui valut la commande par Thiers de La Prise d'Alexandrie qui figure sur l'Arc de Triomphe de Paris (1833-1835). Ce sculpteur genevois intéresse en outre les littéraires par son invention de la statuetteportrait, dont les intimes de Pradier furent les modèles - outre son maitre parisien, il portraitura ainsi Juliette Drouet et sa fille Claire (voir pp. 460-462). La mode en fut telle que le duc de Nemours commanda aussi son effigie à cet ancien auteur de médaillons, qui est aussi un dessinateur aux sources lettrées (Dante, l'Arioste, avant sa sculpture Daphnis et Chloé, retitrée plus allégoriquement La Pêche et la Chasse).

2 Le riche catalogue établi par cette thèse d'histoire de l'art (pp.243-355), outre les planches présentant un choix de ses dessins et médailles, et surtout de sa statuaire (pp. 357-477), permet d'appréhender toutes les facettes du talent de son «romantique mitigé». Influencé par David, Canova et Flaxman, mais aussi par le style troubadour, qui nourrit ses scènes de genre et d'histoire, notamment après son séjour à Naples en 1826-29, il élabore, entre représentation lyrique du corps humain et souci d'exactitude réaliste, une esthétique en fait assez «juste milieu» typique de la Monarchie de Juillet.

Cette première monographie complète sur un artiste qui, faute d'une véritable fortune critique, ne tomba pourtant jamais totalement dans l'oubli, permet au lecteur de visualiser ce qu'ont apprécié les auteurs de la génération romantique, tout en 
apportant de riches informations sur les milieux artistiques - notamment le mécénat et le système de commandes - dans leurs liens avec le monde littéraire. 